American Journal of Pharmaceutical Education 2021; 85 (1) Article 8268.

\title{
BRIEF
}

\section{Impact of Providing a Living Learning Community for First-Year Pre-Pharmacy Students}

\author{
Sarah B. Vincent, PharmD, Wallace Marsh, PhD, MBA, Maria Goodwin, MS, Jane Farr, MA \\ University of New England, Westbrook College of Health Professions, Biddeford, Maine \\ Submitted July 1, 2020; accepted October 14, 2020; published January 2021.
}

Objective. To conduct a retrospective cohort pilot study to evaluate the impact of a living learning community (LLC) designed for undergraduate pre-pharmacy students interested in pursuing a Doctor of Pharmacy (PharmD) degree program.

Methods. Persistence, retention, and progression within the pre-pharmacy program, as well as grade point average (GPA) were measured for LLC students and their pre-pharmacy peers who did not participate in the LLC. Information was obtained from the university's data system and analyzed. Persistence was defined as the student continuing at the university from the fall to spring academic terms. Retention was defined as the student being enrolled at the university during a subsequent fall term. Progression was determined by whether the student had successfully completed the pre-pharmacy curriculum and began pharmacy school within two or three years of initial enrollment in the prepharmacy program.

Results. Despite having admissions characteristics comparable to other pre-pharmacy students, students who participated in the LLC demonstrated significantly higher grade-point averages and retention than their peers who did not participate.

Conclusion. Living learning community programs may be a valuable contributor to pre-pharmacy student success in terms of students' persistence, retention, and progression in a pre-pharmacy program.

Keywords: pre-pharmacy, living learning community, retention

\section{INTRODUCTION}

High-impact educational practices are a set of teaching and learning methods that have been widely studied and, when implemented, proven to have benefits for students from a variety of backgrounds and increase both retention and student engagement. ${ }^{1}$ The American Association of Colleges and Universities (AACU) has identified 11 high-impact practices which include: firstyear seminar experiences, common intellectual experiences, learning communities, collaborative assignments and projects, writing-intensive courses, undergraduate research, diversity and global experiences, e-portfolios, service learning, internships, and capstone courses. ${ }^{1}$ Living learning communities (LLCs) offer a less fragmented approach to a student's academic experience by fostering a sense of deeper learning. ${ }^{2}$ This is accomplished by students living together in a residential community and taking at least one class together, as well as

Corresponding Author: Sarah B. Vincent, University of New England, 88 Sunderland Dr., Auburn, ME 04210. Tel: 207602-2882. Email: svincent2@une.edu integrating course curricula with tangible student experiences outside of the classroom. ${ }^{2}$

That living learning communities have a positive impact on grade point average (GPA), retention, and progression is well documented in the literature. ${ }^{3-6}$ For example, Stassen examined three different types of learning communities at a large public institution. All three models demonstrated increased first-semester academic performance and first to second year retention despite differences in student selection (first-come, firstserved vs application only), major of study (single vs a mix of majors), and residential living requirement. ${ }^{4}$ These results indicate that any efforts to create learning experiences alongside of the curriculum and increased connections between what is learned within the classroom and what is learned outside of the classroom may have lasting benefits for students in measured areas of success such as GPA. ${ }^{4}$ This is of particular importance for undergraduate pre-pharmacy students who typically begin to apply to pharmacy schools during their second year of college. The first undergraduate year is followed by the opening of the pharmacy school admissions cycle, with 


\section{American Journal of Pharmaceutical Education 2021; 85 (1) Article 8268.}

early decision applications due in early September of their second year of undergraduate studies. Thus, these students only have one year of courses prior to submitting their application. Additionally, increased retention efforts will be necessary as applications to pharmacy schools decline nationally. ${ }^{7}$

Connections, support, and transformative experiences allow new students to immediately become immersed within the university, major, and community, enabling them to establish a pattern of involvement early in their academic career. ${ }^{2,8}$ Additionally, LLCs bring students and faculty members together outside of the classroom as well as inside, which may have a significant positive impact on student success. ${ }^{9,10}$ The insights of Spanierman and colleagues were particularly meaningful in relation to creating a sense of belonging among marginalized groups of students. ${ }^{8}$ They used measures of social and academic support, leadership development, and multicultural experiences to be a representation of meaningfulness associated with the LLC. ${ }^{8}$ This creation of meaningfulness was proposed to foster a sense of belonging within the community based on shared experiences. ${ }^{8}$ A study by Bauer and Kiger also supports the concept of meaningfulness, support, and connection created among nursing students by an LLC. ${ }^{11}$ These results may be applicable to students within a pre-pharmacy major because of the unique challenges associated with a short program of study prior to professional schooling. ${ }^{8,11}$

In 2016, the University of New England (UNE) introduced a pre-pharmacy program designed to foster connections and provide support intended to assist in making informed decisions and identity formation, both individually and as a cohort; provide transformative experiences that further support resume building and generate confidence for future experiences; increase the success of its students throughout their education. The three components of this pre-pharmacy program included advising and mentoring, classroom and experiential engagement, and optional participation within a first-year LLC. All first-year pre-pharmacy students were provided advising and mentoring services, as well as classroom and experiential engagement opportunities. Students who participated in the LLC lived on the same residential floor and took at least one class together each semester for their first year of undergraduate studies (fall and spring semester). Commuting students were allowed to participate in all of the LLC activities and classroom experiences without the residential component.

Year-long LLC programming was offered to participating students, as well as additional access to upperclassmen and others within the pharmacy community. Examples of LLC programming included an early orientation to encourage team building within the cohort, a meal and conversation with pharmacy students, programming designed to connect students to resources and support services at the university, and an off-campus trip to volunteer at a community service project led by pharmacy students. Weekly events held during the first month were followed by monthly or twice monthly events held throughout the rest of the year. Events were jointly planned and coordinated by the first-year experience coordinator and a faculty member. From year to year, events varied based on availability and student preferences. Most students attended planned events, as the resident assistant was present to encourage attendance; however, attendance was not mandatory.

In 2019, we conducted a retrospective pilot study to evaluate the impact of the LLC program on those who participated in it compared to their pre-pharmacy peers who did not participate in it. We hypothesized that a higher percentage of students who participated in the LLC would remain in the pre-pharmacy program, have higher GPAs, and progress to the PharmD program.

\section{METHODS}

Students included in this study were first-year, fulltime undergraduate students who entered the program in a fall term and declared a pre-pharmacy major. Students who transferred into the pre-pharmacy program from another major or college at any point past their first semester were excluded from this retrospective cohort study. Students admitted to the pre-pharmacy program shared a variety of backgrounds, with many coming directly from high school. The pre-pharmacy program at the University of New England is a collection of pharmacy school pre-requisite courses that a student can finish within two years of study, although many students choose to complete the program in three years. The PharmD program is designed to be completed in four years.

Although the LLC began in fall 2016, data were collected from 2014-2018. Thus, five years of information were obtained on students not participating in the LLC and three years of data were obtained on students participating in the LLC. Cohort 1 was defined as students who participated in the LLC. Cohort 2 was defined as all students who were enrolled in the pre-pharmacy program during the five years but did not participate in the LLC. Cohort 3 was a subset of cohort 2 and defined as students who chose not to participate in the LLC during the three years it was available. Data were obtained on the following variables: admissions characteristics, persistence and retention of the student across the study years, progression to being a student at UNE College of Pharmacy, and GPA during their first year as a pre-pharmacy student. 


\section{American Journal of Pharmaceutical Education 2021; 85 (1) Article 8268.}

For this study, the markers of success were GPA, persistence, retention, and progression. Persistence was defined as the student continuing at the university from the fall to spring academic terms. Retention was defined as the student being enrolled at the university during a subsequent fall term from when they began at the university. Progression was defined as the student successfully moving from the pre-pharmacy program to the UNE College of Pharmacy within two or three years of initial enrollment in the pre-pharmacy program. This project was approved by the Institutional Review Board of UNE.

Data were both manually entered into an Excel spreadsheet and exported into the sheet from the university reporting system. The data were then analyzed using IBM SPSS, version 25. Descriptive statistics were performed using means and percentages. Statistical tests $(t$ tests and chi-square tests) were used to compare cohorts 1 , 2, and 3 for admissions characteristics, GPA in their first two semesters of college, and persistence, retention, and progression at the university. For all variables, cohort 1 was compared to both cohort 2 and cohort 3. A $p$ value of less than .05 was considered significant.

\section{RESULTS}

Seventy-eight pre-pharmacy students participated in the LLC (cohort 1) and 135 pre-pharmacy students did not participate in the LLC over the five years (Cohort 2) included in the study. Of the 78 LLC students, six were commuting students and the other 72 lived within the LLC residential community. Forty-six students chose not to participate in the LLC during the three years after it was established (Cohort 3). Admissions characteristics for the cohorts of students are shown in Table 1. Students in the cohorts were comparable upon admission to the university based upon high school GPAs and Scholastic Aptitude Test (SAT) scores.

The first semester GPA for Cohort 1 students was 3.5 , while the GPA for cohort 2 was $3.0(t=-6.7 ; p<.01)$.
The first semester GPA for cohort 3 was 3.1 compared to Cohort 1's GPA of $3.5(t=-3.8 ; p<.01)$. The second semester GPA for cohort 1 was 3.2, while the GPA for cohort 2 was $2.9(t=-2.5 ; p=.02)$. A comparison of cohort 1 to cohort 3 showed that the second semester GPA for cohort 3 was $2.6(t=-2.9 ; p=.01)$. Students in the LLC achieved significantly higher course grades than students not participating in the LLC.

The persistence, retention, and progression results for LLC and non-LLC students are shown in Table 2. Nearly all students persisted at the university between the fall and spring of their first year. Non-LLC students' year one retention rate was statistically lower than that for LLC students. While not statistically significant, there was a trend for LLC students to have better second-year persistence from fall to spring semester. About half of LLC students had successful on-time progression to enrollment in the UNE College of Pharmacy, while only about one-third of non-LLC students progressed successfully.

\section{DISCUSSION}

Similar to the findings of other studies of LLCs, our study found significantly better results were obtained for success markers (GPA and year one retention) for students within the LLC compared with those who were not despite their having similar high school GPAs and SAT scores upon admission to UNE. ${ }^{12}$ Similarly, Stassen found a significant positive effect on first-term GPA, as well as year one retention across three different LLCs despite programmatic differences, even when controlling for admissions characteristics, including high school GPA and SAT scores, as well as several others. ${ }^{4}$ Also, Baker and Pomerantz found that students enrolled within learning communities at a commuter metropolitan university earned significantly higher first semester GPAs. ${ }^{13}$

Creating opportunities that fostered interpersonal connections among pre-pharmacy may have contributed to the results found in this study. ${ }^{14}$ Factors that may have

Table 1. Comparison of Admission Characteristics of Pre-Pharmacy Students Participating in a Living Learning Community and Those Not Participating

\begin{tabular}{|c|c|c|c|c|c|}
\hline Admission Characteristic & $\begin{array}{c}\text { Cohort } 1^{a} \\
(n=78)\end{array}$ & $\begin{array}{c}{\text { Cohort } 2^{b}}_{(n=135)}\end{array}$ & $\begin{array}{c}\text { Cohort } 3^{c} \\
(n=46)\end{array}$ & $\begin{array}{c}p \text { value }^{\mathrm{d}} \text { (Cohort } \\
1 \text { to } 2)\end{array}$ & $\begin{array}{c}p \text { value }{ }^{d} \text { (Cohort } \\
1 \text { to } 3)\end{array}$ \\
\hline High school GPA & 3.3 & 3.3 & 3.3 & .64 & .79 \\
\hline Verbal SAT score & 539 & 528 & 538 & .49 & .98 \\
\hline Total SAT score & 1101 & 1081 & 1073 & .47 & .51 \\
\hline
\end{tabular}

Abbreviations: $\mathrm{LLC}=$ living learning community, GPA $=$ grade point average, $\mathrm{SAT}=$ Scholastic Aptitude Test

${ }^{a}$ Cohort $1=$ students participating in the LLC

${ }^{\mathrm{b}}$ Cohort $2=$ all students not participating in the LLC

${ }^{c}$ Cohort $3=$ students not participating in the LLC when it was available

${ }^{\mathrm{d}}$ Results from $t$ tests performed on admission data 


\section{American Journal of Pharmaceutical Education 2021; 85 (1) Article 8268.}

Table 2. Comparison of Pre-pharmacy Students Participating in a Living Learning Community and Those Not Participating

\begin{tabular}{|c|c|c|c|c|c|}
\hline Characteristic $^{\mathrm{a}}$ & $\begin{array}{c}\text { Cohort } 1^{\mathrm{b}} \\
(\%)\end{array}$ & $\begin{array}{c}\text { Cohort } 2^{\mathrm{c}} \\
(\%)\end{array}$ & $\begin{array}{c}\text { Cohort } 3^{\mathrm{d}} \\
(\%)\end{array}$ & $p$ Value $^{+}\left(\right.$Cohort 1 to $\left.2^{\mathrm{e}}\right)$ & $\begin{array}{c}p \text { Value }^{+}(\text {Cohort } \\
1 \\
\left.\text { to } 3^{\mathrm{e}}\right)\end{array}$ \\
\hline Persistence, year 1 & 92.3 & 91.3 & 95.7 & .91 & .46 \\
\hline Persistence, year 2 & 82.8 & 72.3 & 70.0 & .11 & .16 \\
\hline Year 1 to 2 retention & 88.5 & 76.3 & 73.9 & .03 & .04 \\
\hline Year 3 progression to COP & 50.0 & 35.3 & 30 & .05 & .07 \\
\hline Year 3 or 4 progression to $\mathrm{COP}$ & 53.1 & 38.7 & 33.3 & .06 & .73 \\
\hline
\end{tabular}

Abbreviations: $\mathrm{COP}=$ College of Pharmacy

${ }^{a}$ For the purposes of this study, persistence was defined as the student continuing at the university from the fall to spring academic terms, retention was defined as the student being enrolled at the university during a subsequent fall term, and progression was determined by whether the student had successfully completed the pre-pharmacy curriculum and began pharmacy school within two or three years of initial enrollment in the prepharmacy program. Data were obtained from the university's data system

${ }^{\mathrm{b}}$ Cohort 1 = students participating in the LLC

${ }^{\mathrm{c}}$ Cohort 2 = all students not participating in the LLC

${ }^{\mathrm{d}}$ Cohort $3=$ students not participating in the LLC when it was available

${ }^{\mathrm{e}}$ Results from chi-square test

led to these students' success include living in close proximity, attending many of the same classes together, and studying together. While all students in our study received advising and mentoring, the students in the LLC completed additional programming that created opportunities to increase their connection with their faculty advisor and the coordinator of the first-year experience program. This increased access to and support from faculty members and professional staff members, which may also have contributed to the differences seen in the results as this has previously been reported in the literature as a factor promoting student persistence. ${ }^{15}$

Perhaps the largest limitation of this study is that students self-selected into the living learning community. While the faculty advisor individually engaged all deposited students about the LLC program and its potential benefits, some students opted not to participate. Therefore, students who self-select into the LLC may have higher levels of motivation and focus. Additional limitations to this study may include the researchers' inability to control for numerous factors that may affect markers of success, such as first generation to attend college, low income, and/or underrepresented populations.

Taken together, these results imply that the potential benefit of LLCs may outweigh the costs to the institution of establishing the program as the students in our study were already living on campus, taking the same courses as other students, and interacting with faculty members. The packaging of these offerings is slightly different, although marketing and costs of promotion were minimal and considered as part of the admissions process. Indirect costs may be recognized as the cost of increased correspondence between student affairs and faculty members, as well as increased contact time with faculty members. Arguably, these benefits should be a mainstay of practice in any institution regardless.

As this was a pilot study with small cohort numbers, our data are preliminary. As the LLC was only three years old at the time of this writing, no students who participated in the LLC had graduated from pharmacy school yet. Future analyses could include data for graduating pharmacy students, GPA trends for these students within pharmacy school, self-reported student gains on the impact of the program on their engagement, and development of career-ready skills.

\section{CONCLUSION}

This study provided preliminary evidence that a living learning community for pre-pharmacy students supports student success as measured in terms of GPA and retention. Our results may be limited by student self-selection into the community who may be more likely to succeed regardless of the LLC. Regardless, this study illustrates the importance of supporting programs such as this as a key initiative for student success and retention.

\section{REFERENCES}

1. Kuh GD. High-Impact Educational Practices: What they are, who has access to them, and why they matter. Washington, DC:

Association of American Colleges and Universities: 2008.

2. Upcraft ML, Gardner JN, Barefoot BO. Challenging and supporting the first-year student. 1st ed. San Francisco: Jossey-Bass; 2005.

3. Mayhew MJ, Rockenbach AN, Bowman NA, et al. How college affects students. Vol 3. Newark: John Wiley \& Sons, Incorporated; 2016.

4. Stassen ML. Student outcomes: The impact of varying livinglearning community models. Res High Educ. 2003;44(5):581-613. 


\section{American Journal of Pharmaceutical Education 2021; 85 (1) Article 8268.}

5. Jones-White DR, Radcliffe PM, Huesman RL, Kellogg JP. Redefining student success: Applying different multinomial regression techniques for the study of student graduation across institutions of higher education. Res High Educ. 2010;51(2): 154-174.

6. Yancy DC, Sutton-Haywood M, Hermitte E, Dawkins PW, Rainey $\mathrm{K}$, Parker FE. The impact of the freshman academy/learning communities on student progression and engagement. J Negro Educ. 2008;77(3):250-263.

7. Pavuluri N, Aparasu RR, Boje KMK, et al . Consideration of aggressive and strategic approaches to address declining enrollment in US pharmacy schools. Am J Pharm Educ. 2019;83(6):6959. doi:10.5688/ajpe6959. 8. Spanierman LB, Soble JR, Mayfield JB, et al . Living learning communities and students' sense of community and belonging. I Stud Aff Res Prac. 2013;50(3):308-325.

9. Pascarella ET, Terenzini PT. How college affects students. 1st ed. San Francisco: Jossey-Bass; 2005.
10. Dunn MS, Dean LA. Together we can live and learn. SCHOLE: A Journal of Leisure Studies and Recreation Education. 2013;28(1):11-23. 11. Bauer RN, Kiger S. Nursing living-learning communities and student retention: a qualitative study. Nurs Educ Pers. 2017;38(2):75-79. doi: http:// dx.doi.org.une.idm.oclc.org/10.1097/01.NEP.0000000000000093. 12. Hotchkiss JL, Moore RE, Pitts MM. Freshman learning communities, college performance, and retention. Education Economics. 2006;14(2):197-210.

13. Baker S, Pomerantz N. Impact of learning communities on retention at a metropolitan university. J Coll Stud Ret. 2000;2(2):115-126.

14. Inkelas KK, Weisman JL. Different by design: an examination of student outcomes among participants in three types of living-learning programs. J Coll Stud Dev. 2003;44(3):335-368.

15. Pike GR, Schroeder CC, Berry TR. Enhancing the educational impact of residence halls: the relationship between residential learning communities and first-year college experiences and persistence. J Coll Stud Dev. 1997;38(6):609. 